\title{
New Records of Apoica pallida (Olivier, 1792) (Hymenoptera: Vespidae, Epiponini) in Bahia State
}

\author{
Alberto Moreira Silva Neto ${ }^{\bowtie}$, Sergio Ricardo Andena \\ Universidade Estadual de Feira de Santana, e-mail: bio.alberto@gmail.com (Autor para correspondência ${ }^{\bowtie}$ ), sergioricardoandena@gmail.com. \\ EntomoBrasilis 4 (3): 152-153 (2011) \\ Abstract. In this paper we record the occurrence of Apoica pallida (Olivier) (Hymenoptera: Vespidae, Epiponini) in state of Bahia, including taxonomic \\ notes. \\ Keywords: Biogeography; Distribution; Taxonomy.
}

\section{Novos Registros de Apoica pallida (Olivier) (Hymenoptera: Vespidae, Epiponini) no Estado da Bahia}

Resumo. Nesse trabalho registramos a ocorrência de Apoica pallida (Olivier) (Hymenoptera: Vespidae, Epiponini) para o estado da Bahia, incluindo notas taxonômicas.

Palavras-chaves: Biogeografia; Distribuição; Taxonomia.

$\mathbf{T}$ The genus Apoica Lepeletier is currently composed of ten described species (PicketT \& Wenzel 2007) which can be easily recognized by the enlarged ocelli and by the approximation of the eyes on the vertex (RichARDS 1978) These characteristics, as well as the pale colors of some species, are often seen in nocturnal Hymenoptera (RichARDS 1978). The nocturnal habits of Apoica are unique within the tribe Epiponini. With the exception of the vespine Provespa, no other social wasp genus is primarily nocturnal (PicketT \& WENZEL 2007). Caste differentiation is determined by queens, which are in some cases slightly smaller than workers, an atypical situation (RICHARDS 1978; Pickett \& Wenzel 2007). However, Noll et al. (2004) demonstrated that queens and workers are approximately the same size. Their nests are arboreal, usually on a narrow branch. With a very characteristic shape, consists of a single open comb, circular in most species and without envelope (RICHARDS 1978; Wenzel 1998). According to Richards (1978), Apoica is quite closely related to Stelopolybia (= Agelaia, see CARPENTER \& DAY 1988), which was confirmed in phylogenetic studies proposed by CARPENTER (1991), Wenzel and Carpenter (1994) and Noll et al. (2004).

Apoica is widely distributed in the Neotropical region, extending from Mexico to Argentina (CARPENTER \& MARQUES 2001). All species have been found in Brazil except Apoica ellenae Pickett \& Wenzel (PICKETT \& WENZEL 2007). According to RichaRds (1978) and Pickett \& Wenzel (2007), none of the species of Apoica are known to inhabit the Bahia state; however SANTos et al (2007) and SANTos et al (2009) found Apoica pallens (Fabricius) in areas of Cerrado and Atlantic Rain Forest.

Apoica pallida Olivier had been found in Brazil, in the states of Acre, Amapá, Amazonas, Ceará, Goiás, Maranhão, Mato Grosso, Pará, Rondônia, and São Paulo (Richards 1978; Pickett \& Wenzel 2007). The specimens of $A$. pallida seen in this study were deposited in the Johann Becker Entomological Collection at Museu de Zoologia da Universidade Estadual de Feira de Santana and were collected in the municipalities of: A) Cruz das Almas; B) Ituberá; C) Jussari; D) Feira de Santana and E) Porto Seguro (see Figure 1). A. pallens and $A$. pallida have been frequently collected in areas of Cerrado, as cited by Richards (1978), and also in the Atlantic Rain Forest. Unsurprisingly, the specimens found in Bahia were also collected in Atlantic Rain Forest near the Atlantic coast with the exception of one specimen which was collected in Feira de Santana, probably at the campus of the Universidade Estadual de Feira de Santana (UEFS). Feira de Santana is the second biggest town in northeast region of Brazil, severely antropized and considered an Atlantic Rain Forest Caatinga transitional area. This finding might indicated that $A$. pallida also occurs in the semi-arid region in Bahia. However recent extensive expeditions to Pilão Arcado, Senhor do Bonfin, Paulo Afonso, Morro do Chapéu, Seabra, Curaçá, Coribe, Santa Terezinha and Casa Nova as part of Biodiversity Research Program (PPbio) have failed to show any evidence of such species in these localities.

We hope that this note will stimulate more expeditions in Bahia, a poor sampled state in biodiversity.

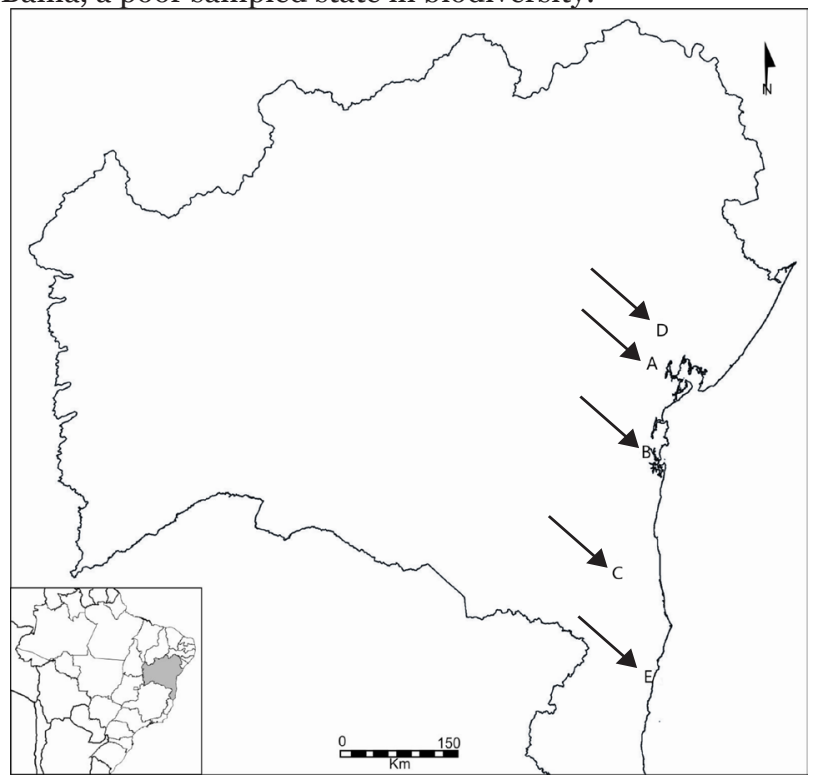

Figure 1: Map of Bahia showing the distribution of Apoica pallida. 


\section{ACKNOWLEDGE}

We dedicate this work to the late Kurt M. Pickett, our friend and who studied the genus Apoica.

\section{REFERENCES}

Carpenter, J.M., 1991. Phylogenetic relationships and the origin of social behavior in the Vespidae, p. 7-32 .In: K.G. Ross \& R.W. Matthews (eds). The Social Biology of Wasps. Cornell University Press, Ithaca, New York, 678p.

Carpenter, J.M, \& M.C. Day, 1988. Nomenclatural notes on Polistinae (Hymenoptera: Vespidae). Proceendings of the Entomological Washington, 90: 323-328.

Carpenter, J.M, \& O.M. Marques, 2001. Contribuição ao Estudo dos Vespídeos do Brasil (Insecta, Hymenoptera, Vespoidae, Vespidae). Universidade Federal da Bahia. Publicações digitais. Vol. 2.

Noll, F.B, J.W. Wenzel, \& R. Zucchi, 2004. Evolution of caste in Netropical swarm-founding wasps (Hymenoptera: Vespidae, Epiponini). American Museum Novitates, 3467: 1-24.

Pickett, K.M., \& J.W. Wenzel, 2007. Revision and cladistic analysis of the nocturnal social wasp genus, Apoica Lepeletier (Hymenoptera, Vespidae, Polistinae, Epiponini). American Museum Novitates, 3562: 1-30.

Richards, O.W., 1978. The Social Wasps of the Americas Excluding the Vespinae. London British Museum (Natural History), 580p.

\section{Como citar este artigo:}

Silva Neto, A.M. \& S.R. Andena, 2011. New records of Apoica pallida (Olivier, 1792) (Hymenoptera: Vespidae, Epiponini) in Bahia State. EntomoBrasilis, 4(3): 152-153. www.periodico.ebras.bio.br/ojs
Santos, G.M.M., C.C. Bichara-Filho, J.J. Resende, J.C. Cruz, \& O. Marques, 2007. Diversity and Community Structure of Social Wasps (Hymenoptera: Vespidae) in Three Ecosystems in Itaparica Island, Bahia State, Brazil. Neotropical Entomology, 36: $180-185$.

Santos, G.M.M, J.C. Cruz, O. Marques, \& N. Gobbi, 2009. Diversidade de vespas sociais (Hymenoptra: Vespidae) em áreas de cerrado na Bahia. Neotropical Entomology, 38:317320.

Wenzel, J.W., 1998. A generic key to the nests of hornets, yellowjackets, and paper wasps worldwide (Vespidae: Vespinae, Polistinae). American Museum Novitates, 3224: 1-39.

Wenzel J.W., \& J.M. Carpenter, 1994. Comparing methods: adaptative traits and tests of adaptation. p. 79-101. In: P. Eggleton, \& Vane-Wright, R. (Eds). Phylogenetics and Ecology. London: Academic Press, 376p.

Recebido em: 14/07/2011

Aceito em: 15/08/2011
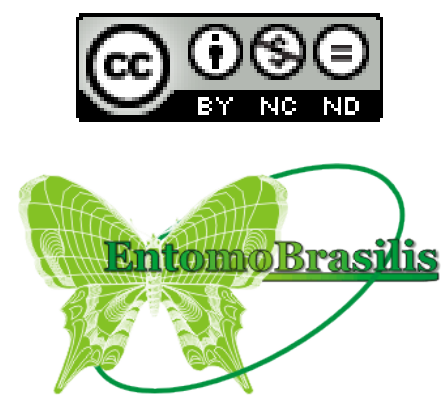

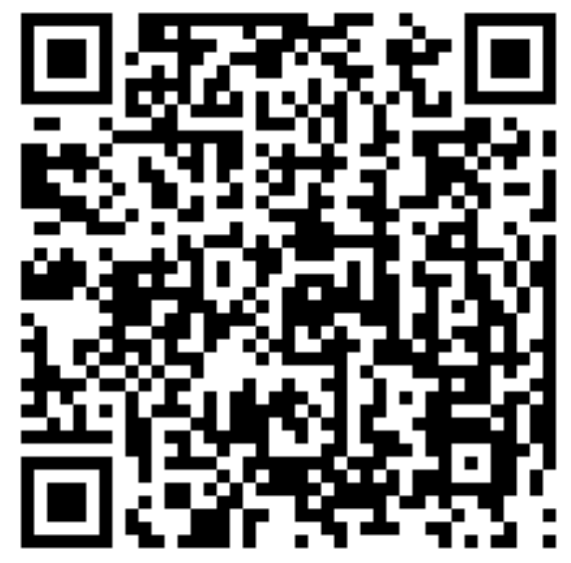

